\title{
Sanggar Anggun Nan Tongga: Pelestarian Kesenian Tradisional Randai (Suatu Kajian Fungsionalis)
}

\author{
Muhammad Reza Fahrizal ${ }^{1}$, Erda Fitriani ${ }^{2}$ \\ ${ }^{1,2}$ Universitas Negeri Padang
}

Email: fahrizalreza28@yahoo.co.id, fitriani_cim@fis.unp.ac.id

\begin{abstract}
Abstrak
Artikel ini bertujuan untuk menjelaskan fungsi Sanggar Anggun Nan Tongga yang ada di Kota Pariaman, Sumatera Barat, dalam melestarikan kesenian tradisional randai Penelitian ini dianalisis dengan teori fungsionalisme dari Bronislaw Malinowski. Penelitian ini dilakukan dengan pendekatan kualitatif, tipe studi kasus. Pemilihan informan dilakukan dengan teknik purposive sampling. Perolehan data penelitian didapatkan dari hasil observasi, wawancara dan studi dokumentasi. Untuk penelitian teknik analisis data digunakan model analisa data dari Miles dan Huberman. Hasil Penelitian yaitu fungsi Sanggar Anggun Nan Tongga dalam melestarikan kesenian tradisional Randai di Desa Talago Sariak Kecamatan Pariaman Utara Kota Pariaman, yaitu: 1) fungsi pelestarian pewarisan nilai, 2) sanggar sebagai sarana edukasi generasi muda dalam mengenal kesenian tradisional randai, 3) Sanggar sebagai wadah pengembangan bakat masyarakat Desa Talago Sariak.

Kata Kunci: Fungsi, Fungsionalis, Kesenian tradisional, Pelestarian, Sanggar

\section{Abstract}

This article aims to explain the function of Sanggar Anggun Nan Tongga in Pariaman City, West Sumatra, in preserving the traditional ant of randai This research was analyzed with the functionalism theory of Bronislaw Malinowski. This research was conducted with a qualitative approach, case study type. The selection of informants was done by purposive sampling technique. Obtaining research data obtained from observations, interviews and documentation studies. For research data analysis techniques used data analysis model from Miles and Huberman. The results of the research are the functions of the Anggun Nan Tongga Studio in preserving Randai traditional arts in Talago Sariak Village, North Pariaman District, Pariaman City, namely: 1) the function of preserving the inheritance of values, 2) the studio as a means of educating the younger generation in recognizing traditional randai arts, 3) The studio as a forum for developing the talents of the people of Talago Sariak Village.

Keywords: Function, Functionalist, Preservation, Studio, Traditional art
\end{abstract}

\begin{tabular}{l|l|l} 
Received: October 21, 2021 & Revised: December 16, 2021 & Published: December 20, 2021
\end{tabular}

Culture \& Society: Journal of Anthropological Research Vol. 3, No. 2, Th. 2021 
Muhammad Reza Fahrizal, Erda Fitriani

\section{Pendahuluan}

Sanggar adalahsuatu tempat atau sarana yang digunakan oleh suatu komunitas atau sekumpulan orang untuk melakukan suatu kegiatan. Selain itu sanggar juga merupakan salah satu lembaga pelatihan yang termasuk ke dalam jenis pendidikan non formal (Purnama, 2015). Sanggar juga dapat diartikan sebagai sebuah tempat atau sarana yang digunakan oleh suatu komunitas atau sekelompok orang untuk berkegiatan seni seperti seni tari, seni lukis, seni kerajinan atau seni peran (Hadie, 2015). Pada saat sekarang ini eksistensi sanggar untuk melestariKan kesenian tradisional sudah mulai memudar (Pertiwi, 2017). Hal demikian dapat dilihat, masyarakat mengikuti tren-tren budaya modern dan seakan melupakan budayanya sendiri. Padahal budaya lokal merupakan ciri khas yang menjadi kebanggaan tersendiri bagi masyarakat tersebut. Hal terpenting dalam pelestarian dan pengembangan kebudayaan ini adalah bahwa kebudayaan tidak diwariskan secara genetika melainkan melalui proses pembelajaran yang terus-menerus (Sonia \& Sarwoprasodjo, 2020).

Berdasarkan pernyataan di atas dapat dijelaskan bahwa sifat kebudayaan diperoleh melalui pendidikan, salah satunya yaitu pendidikan non formal yaitu jalur pendidikan di dalam suatu latar yang berstruktur, yaitu terjadi di luar sistem pendidikan formal. Sanggar berfungsi mengembangkan potensi pemuda-pemudi dengan penekanan pada penguasaan pengetahuan dan keterampilan fungsional serta pengembangan sikap dan kepribadian profesional (Pertiwi, 2017). Sanggar seni dan budaya ini dijadikan sebagai wadah bagi masyarakat untuk memperoleh ilmu pengetahuan dan pengembangan diri khususnya dalam bidang seni dan budaya. Hal demikian juga dilakukan oleh Sanggar Anggun Nan Tongga. Sanggar Anggun Nan Tongga terletak di Desa Talago Sariak, Kecamatan Pariaman Timur, Kota Pariaman. Sanggar Anggun Nan Tongga berdiri pada 24 Oktober 2016, berdasarkan azaz musyawarah dan mufakat dengan pemuka adat, tokoh masyarakat beserta pemuda Desa Talago Sariak.

Sanggar Anggun Nan Tongga merupakan kelompok sanggar yang ikut mempertahankan kesenian tradisional. Kesenian tradisional yang terus dipertahankan oleh sanggar tersebut pada saat sekarang ini seperti kesenian tradisional randai Sanggar dijadikan sebagi tempat pelestarian dapat dibagi dalam dua aspek yaitu mempertahankan dan mengembangkan kesenian tradisional (Putri, 2015). Sanggar ini merupakan gagasan dari Badan Usaha Milik Desa yang langsung didanai oleh Desa Talago Sariak. Sanggar Anggun Nan Tongga ini dijadikan sebagai wadah untuk berkreasi dan berimajinasi dengan penuh inovasi untuk kesenian dan kebudayaan, dengan sasaran kegiatan masyarakat Desa Talago Sariak khususnya bagi pemuda-pemudi yang masih sekolah (SD, SLTP, SMA) serta bertujuan menumbuh kembangkan tentang pentingnya melestarikan kesenian tradisi Kota Pariaman serta menjauhkan para generasi muda dari kegiatan negatif namun mendekatkan ke kegiatan yang positif. Adanya sanggar sebagai wadah untuk pertunjukan tradisional berfungsi sebagai penuntun dan pembawa pesan moral untuk masyarakat pemiliknya (Bahardur, 2018). Fungsi tersebut dilaksanakan sesuai dengan tahapan tertentu dalam pelaksanaannya.

Pelestarian kesenian tradisional randai yang diwadahi oleh sanggar ini juga didukung dengan adanya Peraturan Daerah Provinsi Sumatera Barat Nomor 6 pasal 13 tahun 2014 mengenai "Pelestarian nilai budaya Minangkabau" (Barat G. S., 2014). Upaya yang dilakukan oleh Sanggar Anggun Nan Tongga dalam menarik minat generasi muda Desa Talago Sariak yaitu melakukan sosialisasi kepada pemuda-pemudi Desa Talago Sariak dengan menyadarkan mereka untuk mencintai budaya Minangkabau sebagai kesenian tradisional. Kemudian pada saat sekarang ini Pemerintah Kota Pariaman sering mengadakan perlombaan festival kesenian tradisional, sehingga membuat para generasi muda tertantang untuk memperlihatkan kualitas dirinya dengan berbagai keuntungan yang mereka dapatkan dari mengikuti festival kesenian tradisional tersebut.

Bentuk keberhasilan dari Sanggar Anggun Nan Tongga ini dalam menjalan fungsinya untuk melestarikan kesenian tradisional adalah: Kegiatan-kegiatan sanggar yang berjalan dengan

Culture \& Society: Journal of Anthropological Research Vol. 3, No. 2, Th. 2021

2686-343X (E-ISSN) 2686-3421 (P-ISSN)

Copyright (C) 2021, by Author. 
Muhammad Reza Fahrizal, Erda Fitriani

baik dan terorganisir sejak tahun 2016 sampai sekarang. Kemudian Sanggar Anggun Nan Tongga ini juga ikut memeriahkan beberapa pentas seni budaya yang diadakan oleh Pemerintah Kota Pariaman dan Sumatera Barat. Seperti melakukan pergelaran Randai Suruang lingkup Sumatera Barat. Kemudian juga berkontribusi langsung pada Festival Budaya Tabuik pada tahun 2017 dan 2018. Selanjutnya pada saat sekarang Pemerintah Kota Pariaman begitu gencarnya menggalakkan pariwisata Kota Pariaman, setiap bulannya di Kota Pariaman selalu diadakan acara yang berkaitan dengan kesenian tradisional, yaitu beragamnya kegiatan kesenian tradisional yang dilakukan dalam acara Pariwisata Kota Pariaman tahun 2019.

Berdasarkan dengan adanya permasalahan tersebut, peneliti ingin mengetahui mengenai fungsi sanggar Anggun Nan Tongga dalam melestarikan kesenian tradisional randai. Penulis tertarik untuk melakukan penelitian tentang fungsi sanggar Anggun Nan Tongga dalam melestarikan kesenian tradisional randai karena kesenian randai sudah kurang diminati. Adanya salah satu kesenian modern yang lebih disukai terutama dikalangan anak muda seperti game online. Sebagai akibatnya, kesenian tradisional randai yang selama ini telah melekat pada masyarakat lambat-laun akan menghilang. Maka dari itu perlu adanya fungsi dari Sanggar Anggun Nan Tongga dalam melestarikan kesenian tradisional Randai.

Penelitian mengenai sanggar telah dilakukan oleh banyak peneliti lain, diantaranya pertama, Ardipal yang berjudul Peran Partisipan sebagai Bagian Infrastruktur Seni di Sumatera Barat: Perkembangan Seni Musik Talempong Kreasi. Temuannya menunjukkan bahwa talempong tradisi berhasil dikembangkan oleh tokoh partisipan akademik. Kedua, penelitian dari Maryelliwati yang berjudul Peran Sanggar Seni Aguang dalam Pengembangan dan Pelestarian Seni di Padang Panjang. Temuannya adalah Kesenian Padang Panjang Sumatera Barat [khususnya] telah berkembang pesat. Aguang di Padang Panjang secara umum berasal dari seni bela diri yaitu silat/silek tuo (silek Arimau). Ketiga, penelitian dari Aziz Mei Kurnianto yang berjudul Peran Sanggar Seni Pemuda Edi Peni dalam Pelestarian Budaya Lokal di Desa Hadiluwih Kecamatan Ngadirojo Kabupaten Pacitan. Temuannya adalah peran dari Sanggar Seni Pemuda Edi Peni sendiri adalah tempat untuk pelestarian dan juga tempat menjaga kebudayaan khususnya budaya lokal. Keempat, penelitian dari Nirwana yang berjudul Peran Sanggar Seni Pemuda Edi Peni dalam Pelestarian Budaya Lokal di Desa Hadiluwih Kecamatan Ngadirojo Kabupaten Pacitan. Penelitian yang saya kaji, memiliki keunikan dari penelitian relevan sebelumnya. Peneltian ini melihat bagaimana fungsi sanggar Anggun Nan Tongga dalam mempertahankan kesenian tradisional randai di era kemajuan teknologi dan gaya ikutikutan tren oleh anak muda sekarang.

\section{Metode Penelitian}

Penelitian ini dilakukan di Desa Talago Sariak, Kecamatan Pariaman Timur, Kota Pariaman, Sumatera Barat. Alasan peneliti memilih Sanggar Anggun Nan Tongga sebagai tempat penelitian dikarenakan sanggar ini terorganisir dalam berkontribusi menjaga kelestarian kesenian tradisional randai khususnya di Kota Pariaman. Selanjutnya sanggar ini baru berdiri pada tahun 2016 namun sudah memiliki perkembangan yang cukup pesat, seperti aktif dalam melakukan pergelaran randai se-Sumatera Barat. Kemudian juga berkontribusi langsung pada Festival Budaya Tabuik pada tahun 2017 dan 2018. Untuk itu Sanggar Anggun Nan Tongga ini tepat dijadikan sebagai lokasi penelitian. Penelitian ini dianalisis dengan metode pendekatan penelitian kualitatif. Dilihat dari segi jenisnya penelitian ini termasuk studi kasus. Dikatakan demikian, karena penulis melakukan penelitian berdasarkan pedoman penelitian. Kemudian dari pedoman penelitian tersebut, penulis membuat pertanyaan-pertanyaan kecil berdasarkan informasi yang disampaikan informan sampai penulis memperoleh informasi yang lebih jelas dan mendalam terkait topik penelitian ini. (Yusuf, 2014).

Culture \& Society: Journal of Anthropological Research Vol. 3, No. 2, Th. 2021 
Muhammad Reza Fahrizal, Erda Fitriani

Pemilihan informan menggunakan teknik purposive sampling. Subjek penelitiannya yaitu pengurus yang terlibat dalam Sanggar Anggun Nan Tongga dan tokoh masyarakat Desa Talago Sariak serta masyarakat yang tinggal di Desa Talago Sariak. Total informan mencapai 12 (dua belas) orang informan. Teknik pengumpulan datanya yaitu : 1) Observasi non partisipasi (non participant observation). Pada saat observasi peneliti mengamati aktivitas atau kegiatan yang dilakukan oleh seluruh anggota Sanggar Anggun Nan Tongga. Pengamatan langsung yang dilakukan di lapangan, membantu peneliti dalam proses pencarian data yaitu fungsi Sanggar Anggun Nan Tongga. 2) Wawancara mendalam, wawancara mendalam ini bersifat terstruktur dan proses tanya jawab mengalir seperti percakapan sehari-hari. Pada saat sekarang ini dikarenakan situasi Covid 19 masih belum stabil, pada saat proses wawancara peneliti dan informan berinteraksi sesuai dengan anjuran protokol kesehatan yaitu dengan memakai masker dan menjaga jarak. 3) Studi dokumentasi yaitu dengan mengumpulkan berbagai dokumen dalam menjawab pertanyaan mengenai fungsi Sanggar Anggun Nan Tongga (Yusuf, 2014). Selanjutnya dalam menganalisis data, peneliti menggunakan model analisis interaktif Miles dan Huberman yaitu reduksi data, display data dan penarikan kesimpulan (Silalahi, 2009).

\section{Hasil dan Pembahasan}

\section{Lokasi Penelitian Desa Talago Sariak}

Desa Talago Sariak terletak di Kecamatan Pariaman Timur, Kota Pariaman, Provinsi Sumatera Barat dengan luas 1,25 KM Persegi. Desa Talago Sariak terdiri dari empat dusun yaitu Dusun Tengah, Dusun Lubuk, Dusun Simpang Raya dan Dusun Bawah Tempat. Pada mulanya Desa Talago Sariak terbentuk karena adanya Talago (Telaga) dan Sariak (Sejenis Bambu). Di tengah tengah telaga tersebut tumbuh batang Sarik. Konon katanya air telaga surut disebabkan oleh orang sakti yang sengaja menutup aliran mata air telaga tersebut, sehingga terbentuklah pemukian di daerah sekitar telaga yang sekarang menjadi desa bernama Talago Sariak. Desa Talago Sariak terdapat sanggar, berdiri pada tanggal 24 Oktober 2016 berdasarkan azaz musyawarah dan mufakat dengan pemuka masayarakat atau tokoh masyarakat beserta pemuda Desa Talago Sariak. Kami membentuk sebuah sanggar "ANGGUN NAN TONGGA" yang berarti Angkatan Unggul Nagari Talago Sariak yang bertujuan sebagai wadah untuk berkreasi dan berimajinasi dengan penuh inovasi untuk kesenian dan kebudayaan, dengan sasaran kegiatan masyarakat Desa Talago Sariak khususnya bagi pemuda-pemudi yang masih sekolah (SD, SLTP, SMA), menumbuh-kembangkan kesenian dann melestarikan kesenian tradisi Pariaman serta menjauhkan dari hal negatif serta mendekatkan pada hal positif.

Sanggar Anggun Nan Tongga memiliki sekretariat di Karang Taruna "ABADI" Desa Talago Sariak dengan sama-sama membentuk generasi muda yang kompeten baik dari segi agama maupun budaya.

\section{Fungsi Sanggar Anggun Nantongga dalam Pelestarian Randai}

Berdasarkan hasil observasi dan wawancara yang peneliti lakukan di Sanggar Anggun Nan Tongga peneliti menemukan beberapa fungsi sanggar dalam melestarikan kesenian randai tradisional Minangkabau antara lain sebagai berikut:

\section{Fungsi Pelestarian Pewarisan Randai}

Kebudayaan adalah sistem dari pola-pola tingkah laku yang diturunkan secara sosial yang bekerja menghubungkan komunitas manusia dengan ekologi mereka. Pergeseran nilai-nilai budaya dalam masyarakat terjadi seiring pengaruh dari globalisasi dan pengaruh budaya lain. Melalui kegiatan yang dilakukan oleh Sanggar Anggun Nan Tongga, pengaruh pergeseran dari nilai-nilai budaya tersebut dapat di atasi. Pernyataan di atas seperti diungkapkan oleh salah seorang informan, wawancara dilakukan pada tanggal 15 Agustus, hari Minggu 2021 dengan Bapak Rahmad Nadisyah S.Pd.:

Culture \& Society: Journal of Anthropological Research Vol. 3, No. 2, Th. 2021 
“...Menurut saya Sanggar Anggun Nan Tongga ini sanggat membantu untuk melestarikan kesenian tradisional yang sudah mulai dilupakan, salah satunya kesenian tradisional randai, yang mulai dilupakan oleh generasi muda pada zaman kemajuan teknologi yang mana banyak dari anak-anak lebih memilih memainkan permainan dari HP, seperti Game Online. Untuk itu anak muda diberi wadah dalam mengenal yang namanya randai agar anak muda ini kembali antusias dalam memainkan kesenian tradisional randai, Sanggar Anggun Nan Tongga ini jadi tempat untuk anak muda mengenal kesenian tradisional randai".

Sanggar Anggun Nan Tongga memiliki fungsi untuk mempertahankan kesenian tradisional randai dari pergeseran nilai-nilai budaya. Generasi muda saat ini, sangat mudah dipengaruhi oleh kebudayaan seperti permainan game online. Selain itu keberadaan sanggar sangat membantu generasi muda dalam mengenal kesenian tradisional randai.

Sanggar Anggun Nan Tongga merupakan tempat anak-anak belajar kesenian tradisional Minangkabau. Dengan adanya sanggar, generasi muda dapat menyeimbangkan antara kesenian tradisional dan modern. Pernyataan ini seperti yang diungkapkan oleh salah seorang informan ibu Ratnawati, wawancara 16 Agustus 2021:

"Melihat bagaimana perkembangan zaman pada saat ini, permainan randai sudah mulai dilupakan, permainan randai pada saat ini sangat jarang terlihat dimainkan oleh generasi muda. Karena HP anak muda tidak berminat memainkan randai lagi. Saya sanggat mendukung adanya Sanggar Anggun Nan Tongga ini, yang mana menjadi wadah untuk generasi muda belajar memainkan kesenian tradisional Randai, yang paling menarik menurut saya sanggar ini mulai mengajar anak-anak di usia tingkat SD dan SMP, yang mana anak-anak ini belum terpengaruh oleh kemajuan teknologi karena anak-anak ini tidak diberi HP oleh orang tuanya. Kalau dari usia anak SD dan SMP mudah mudahan anak-anak menjadikan hobby kesenian tradisional randai ini dan memainkannya di zaman kemajuan teknologi pada saat ini".

Munculnya sanggar di desa ini dalam rangka melestarikan kesenian ttradisional juga mendapat dukungan dari pemerintah desa. Seperti yang diungkapkan oleh Kepala Desa Talago Sariak, Bapak Ahmad Fahmi, S.Pd. wawancara pada hari Jumat tanggal 20 Agustus 2021.

"Sanggar ini sangat perlu di era perkembangan zaman digital ini, yang mana anakanak lebih memilih kebudayaan luar, seperti permainan game dari HP. Untuk itu sanggar ini dibentuk melalui rapat secara bersama. Melalui dana desa di bawah naungan BUMDES. Berdisinya sanggar ini atas kesepakatan dan musyawarah kami bersama. Selain pendidikan formal yang ada di sekolah, pendidikan non-formal inilah yang membantu anak-anak untuk mengenal kesenian Pariaman. Salah satunya randai, yang memiliki cerita khas dari pertunjukan randai Pariaman yaitu cerita Anggun Nan Tongga Magek Jabang (Gelar). Dari sanggar inilah mudah-mudahan generasi muda lebih antusias untuk belajar dan memainkan pertunjukan randai ini".

Dengan demikian berhasilnya sebuah sanggar dalam melestarikan kesenian randai karena mendapat dukungan dari pemerintah desa, terutama mereka mendapatkan saran yang dijakan sebagai sekretarian, dan sanggar juga mendapatkan dana dari Bundesa. Tujuan pemerintah yaitu melalui pendidikan non formal seperti sanggar ini dapat mengenalkan kesenian tradisional randai pada generasi muda dan randai ini dapat bertahan oleh perkembangan zaman. Selain itu dapat melestarikan randai khas Pariaman Anggun Nan Tongga Magek Jabang, dan dipelajari oleh generasi muda desa.

Culture \& Society: Journal of Anthropological Research Vol. 3, No. 2, Th. 2021 
Muhammad Reza Fahrizal, Erda Fitriani

\section{Fungsi Edukasi: penanaman nilai}

Menurut (Rusliana, 1990), sanggar adalah wadah kegiatan dalam membantu dan menunjang keberhasilan dan penguasaan dalam bidang pengetahuan dan keterampilan. Sanggar seni adalah tempat atau wadah bagi manusia melakukan atau mempelajari suatu kesenian yang bertujuan untuk selalu menjaga kelestariannya di masyarakat. Sanggar juga bertujuan untuk menanamkan nilai-nilai arif kebudayaan di lingkungan masyarakat yang dipelajari dari proses dalam sanggar tersebut. Pernyataan di atas sejalan dengan pernyataan informan pada saat wawancara bersama Bapak Junaidi Tanjung selaku pelatih randai pada hari Senin tanggal 23 Agustus 2021:

"Selama saya menjadi pelatih sanggar ini saya menekankan pada anak didik saya untuk serius dalam belajar dan memahami kesenian tradisional randai ini, agar anak didik saya dapat pengetahuan tentang pentingnya menjaga kelestarian tradisional Minangkabau terutama kesenian randai yang mulai pudar, untuk itu saya mengajarkan nilai-nilai yang terkandung didalam Randai ini. Seperti nilai kekompakan, solidaritas dan kebersamaan. Serta anak didik saya dapat mengamalkan nilai-nilai yang mereka dapatkan dari proses belajar di sanggar dalam kehidupan sehari-hari".

Berdasarkan hasil wawancara dengan informan, menyatakan bahwa nilai-nilai yang terkandung dalam proses belajar di sanggar sangat diperlukan untuk peserta didik sanggar. Hal demikian dimaksudkan agar tumbuhnya rasa untuk mempertahankan kesenian tradisional randai. Supaya randai tetap dimainkan di era perkembangan zaman, serta peserta didik dapat mengamalkan nilai-nilai kekompakan, solidaritas dan kebersamaan di tengah kehidupan masyarakat.

Hal senada juga disampaikan pada saat wawancara bersama informan Bapak Mahmud Juanda selaku pelatih Randai pada hari Senin Tanggal 23 Agustus 2021 beliau menyampaikan sebagai berikut:

Dari pembelajaran kelompok di sanggar ini anak didik kami dapat mengenal kesenian tradisional randai, sama-sama kita ketahui banyak pelajaran yang kita ambil dari kesenian ini. Salah satunya kekompakan, agar permainan ini indah, maka dibutuhkan kekompakan dalam memainkannya, karena dalam memainkan randai harus senada dan seirama, dari sinilah kami mengajari anak didik agar teratur dalam kehidupan bermasyarakat, anak didik kami juga ditekankan untuk memahami bagaimana kesenian randai ini berangsur-angsur dilupakan karena perkembangan zaman. Sanggar berfungsi untuk melestarikan kesenian Minangkabau yang mulai terkikis oleh perkembangan zaman. Saya sangat senang sekali dengan adanya sarana belajar randai disanggar ini, disamping untuk mempertahankan kesenian tradisional randai, juga anak-anak dapat belajar nilai-nilai arif yang terkandung dalam permainan Randai ini.

Dari penyataan beberapa informan diketahui bahwa fungsi sanggar Anggun Nan Tongga sangat membantu untuk memberikan edukasi kepada masyarakat dalam memahami kesenian tradisional randai. Keberadaan sanggar bukan hanya sebagai media belajar randai melainkan juga mengajarkan anak didik untuk taat dan teratur dalam kehidupan bermasyarakat, menjaga solidaritas atau kekompakan.

\section{Fungsi Sanggar Sebagai Wadah Pengembangan Bakat}

Randai bagi masyarakat Minangkabau tidak sekedar salah satu bentuk kesenian tradisi. Akan tetapi, randai juga merupakan media pendidikan dan pengajaran tentang falsafah, etika, dan adat bagi masyarakat. Dalam randai memuat nilai-nilai hidup. Randai merupakan teater tradisional dan sekaligus juga teater rakyat Minangkabau yang mempunyai ciri-ciri sebagai

Culture \& Society: Journal of Anthropological Research Vol. 3, No. 2, Th. 2021 
berikut (Primadesi, 2013): Ciri yang pertama yakni cerita yang dimainkan bersumber dari kaba atau cerita lisan yang populer dalam masyarakat untuk kemudian dibuatkan naskah atau skriptnya.

Kedua, penyampaian cerita bukan hanya dalam bentuk dialog, tetapi juga dalam bentuk nyanyian yang diiringi bunyi-bunyian seperti talempong, saluang, rabab, dan gandang. Ketiga, nilai dramatik dikembangkan melalui improvisasi pemain dan pada umumya bersifat spontan. Keempat, terdapat hubungan yang akrab antara pemain dengan penonton, serta pertunjukkan itu sendiri dengan penonton. Kelima, randai biasanya dimainkan di alam terbuka yang disebut medan nan bapaneh. Keenam, pertunjukan randai sangat bersifat fleksibel dalam hal cerita dan waktu. Dalam melestarikan kesenian tradisional andai peran masyarakat sangatlah penting. Hal tersebut senada dengan pernyataan salah seorang informan yaitu Bapak Afrialdi selaku tokoh pemuka adat pada hari Rabu Tanggal 1 September 2021:

"Menurut saya adanya sanggar ini sangat membantu generasi muda untuk mengetahui kebudayaan yang ada di Minangkabau. Tidak hanya itu keberadaan sanggar juga perlu untuk pengembangan keterampilan dan bakat yang telah lama tidak diasah. Kini setiap sore dan malam anak-anak pergi bersama untuk belajar randai dan Tambua Tansa. Sekarang suana desa telah kembali seperti dulu, anak anak Desa Sungai Sarik sudah mengenal kesenian masyarakat Minangkabau".

Keberadaan sanggar sanggat berguna untuk mengembangkan keterampilan dan bakat anak-anak atau generasi muda, serta pelatihan yang terus-menerus menyebabkan keterampilan bermain randai mereka terus terasah sehingga menjadi lebih bagus. Keberadaan sanggar Anggun Nan Tongga, anak anak desa mulai antusias berlatih kesenian tradisional yang ada di Minangkabau terutama randai.

Hal yang hampir sama disampaikan oleh Bapak Edra, A.Md. selaku ketua BUMDES pada wawancara hari Sabtu Tanggal 4 September 2021.beliau menyatakan sebagai berikut: sanggar ini adalah salah satu program pengembangan bakat untuk masyarakat desa, terutama untuk generasi muda era teknologi ini. Karena itu kami sepakat mendirikan sanggar ini sebagai pengembangan bakat yang ada pada diri anak-anak tersebut. Salah satunya kesenian tradisional seperti randai ini yang dirancang dalam program belajar di sanggar ini. Di sini banyak hal positif yang didapatkan oleh anak-anak tersebut, seperti kepandaian bermain alat musik, silat, drama, theater yang merupakan bagian dari gabungan randai tersebut. Bukan hanya itu saja yang didapat oleh mereka, mereka juga dapat tambah uang jajan dari penampilan di acara pesta pernikahan yang telah mengundang sanggar ini dan juga ada sedikit pemasukan untuk desa. hal paling membanggakan menurut kami adalah mereka sudah ikut memeriahkan fetival anak nagari yang di gelar oleh pemerintah Kota Pariaman, walaupun sanggar ini berdiri pada tahun 2016 tapi sanggar ini sudah ikut memeriahkan acara festival Tabuik, anak nagari dan lain' juga mengisi acara di pesta pernikahan.

Dengan demikian dapat dipahami bahwa terdapat tiga fungsi dari keberadaan sanggar Anggun Nan Tongga. Pertama, fungsi pelestarian warisan randai, kedua fungsi edukasi nilainilai yang ada pada randai seperti nilai kekompakan, keberanian, keteraturan, dan keindahan. Ketiga fungsi sanggar adalah sebagai wadah pengembangan bakat. Bakat yang dimiliki oleh anak-anak tidak akan dapat ter-asah dengan baik, jika tidak dilatih secara kontinue. Artinya dengan adanya sanggar ini, anak generasi muda yang pada dasarkan adalah anak-anak yang sedang usia sekolah, seperti SD, SMP dan SMA, dapat memiliki kesempatan untuk melatih kemampuannya.

\section{Analisa Fungsionalis pada keberadaan sanggar Anggun nan Tongga}

Dari hasil wawancara dan pengamatan yang dilakukan oleh penulis selama berada di Desa Talago Sariak, Kecamatan Pariaman Timur, Kota Pariaman bahwa ada 3 fungsi sanggar dalam

Culture \& Society: Journal of Anthropological Research Vol. 3, No. 2, Th. 2021 
melestarikan kesenian tradisional randai yaitu, Sanggar dalam menjalankan fungsi pelestarian pewarisan nilai, sanggar sebagai sarana edukasi generasi muda dalam mengenal kesenian tradisional randai, sanggar sebagai pengembangan bakat anak nagari Desa Talago Sariak.

Jika merujuk pada teori fungsional yang berasumsi bahwa semua unsur kebudayaan bermanfaat bagi masyarakat di mana unsur itu terdapat. Dengan kata lain, pandangan fungsionalisme terhadap kebudayaan mempertahankan bahwa setiap pola kelakukan yang sudah menjadi kebiasaan, setiap kepercayaan dan sikap yang merupakan bagian dari kebudayaan dalam suatu masyarakat, memenuhi beberapa fungsi mendasar dalam kebudayaan bersangkutan. Menurut Malinowski, fungsi dari satu unsur budaya adalah kemampuannya untuk memenuhi kebutuhan dasar atau beberapa kebutuhan yang timbul dari kebutuhan dasar yaitu kebutuhan sekunder dari para warga masyarakat (Ihromi. T.O, 2006).

Menurut Malinowski adalah kemampuan keterampilan analitik agar dapat memahami latar dan fungsi dari aspek yang diteliti, adat dan pranata sosial dalam masyarakat. Konsep tersebut dirumuskan kedalam tingkatan abstraksi mengenai fungsi aspek kebudayaan, yakni: (1) Saling keterkaitannya secara otomatis, pengaruh dan efeknya terhadap aspek lainnya. (2) Konsep oleh masyarakat yang bersangkutan. (3) Unsur-unsur dalam kehidupan sosial masyarakat yang terintegrasi secara fungsional. (4) Esensi atau inti dari kegiatan /aktifitas tersebut tak lain adalah berfungsi untuk pemenuhan kebutuhan dasar "biologis" manusia.

Melalui tingkatan abstraksi tersebut Malinowski kemudian mempertegas inti dari teorinya dengan mengasumsikan bahwa segala kegiatan/aktifitas manusia dalam unsur-unsur kebudayaan itu sebenarnya bermaksud memuaskan suatu rangkaian dari sejumlah kebutuhan naluri mahluk manusia yang berhubungan dengan seluruh kehidupannya. Kelompok sosial atau organisasi sebagai contoh, awalnya merupakan kebutuhan manusia yang suka berkumpul dan berinteraksi, perilaku ini berkembang dalam bentuk yang lebih solid dalam artian perkumpulan tersebut dilembagakan melalui rekayasa manusia (Ihromi. T.O, 2006). Langkah ini dilakukan untuk mempertahankan pola-pola yang sudah menjadi kebiasaan dalam kehidupan masyarakat Desa Talago Sariak dari kontak budaya luar.

Di era perkembangan teknologi generasi muda sangat mudah dipengaruhi oleh budayabudaya yang datang dari luar. Sanggar anggun nan tongga menjadi sebuah struktur Sosial yang bertujuan menjaga kelestarian kebudayaan yang dipercayai masyarakat Talago Sariak sejak lama, salah satunya randai Sanggar Anggun Nan Tongga sabagai pranata sosial membentuk sistem baru yang mampu mengajak masyarakat Desa Talago Sariak untuk kembali antusias dalam mempelajari kebudayaan kesenian randai yang hampir punah. Sanggar sebagai sebuah pranata sosial memiliki fungsi sebagai wadah untuk melatih generasi muda untuk mempelajari kesenian randai. Namun sanggar atau pun kesenian randai itu sendiri memiliki keterkaitan fungsi dengan subsistem yang lain. Yaitu sangar sebagai media pendidikan, penanaman nilai karakter dan sanggar dapat mengembangkan bakat dari anak. Selain fungsi pendidikan dari sanggar, juga memiliki fungsi ekonomi, yaitu peserta yang ikut dalam pertunjukan randai, juga dapat menerima penghasilan, dengan demikian sanggar juga memiliki fungsi ekonomis.

\section{Kesimpulan}

Berdasarkan hasil observasi dan wawancara yang dilakukan oleh peneliti dengan informan di lapangan yang dilengkapi dengan data-data tertulis, data lisan dan data sekunder seperti dokumen, arsip, skripsi-skripsi yang relevan dengan penelitian ini, maka diperoleh bukti dan informasi yang menjelaskan bahwa: fungsi dari sanggar Anggun nan Tongga yaitu: Pertama, fungsip pelestarian nilai, pergeseran nilai-nilai budaya dalam masyarakat terjadi seiring pengaruh dari globalisasi dan pengaruh budaya lain. melalui kegiatan yang dilakukan oleh Sanggar Anggun Nan Tongga pengaruh dari nilai-nilai budaya luar tersebut dapat diatasi. Kedua, Sanggar sebagai sarana edukasi generasi muda dalam mengenal kesenian tradisional randai, Sanggar

Culture \& Society: Journal of Anthropological Research Vol. 3, No. 2, Th. 2021 
Muhammad Reza Fahrizal, Erda Fitriani

Anggun Nan Tongga berupaya mengedukasi generasi muda agar lebih antusias dalam mempelajari kebudayaan tradisional Minangkabau. Ketiga, sanggar sebagai wadah pengembangan bakat masyarakat Desa Talago Sariak. Dalam melestarikan kesenian tradisional randai peran masyarakat sangatlah penting. Keberadaan sanggar sanggat berguna untuk mengembangkan keterampilan dan bakat masyarakat yang telah lama tidak diasah. Adanya Sanggar Anggun Nan Tongga, anak-anak desa mulai antusias dengan kesenian tradisional yang ada di Minangkabau terutama randai. Sanggar Anggun Nan Tongga sangat diberi apresiasi karena anak-anak yang belajar di sanggar ini sudah menampilkan bakatnya di acara Festival Tabuik, anak nagari dan festival kebudayaan lainya. Keberadaan sanggar ini dapat berkembang karena dukungan dari masyarakat dan pemerintah desa.

\section{Daftar Pustaka}

Bahardur, I. (2018). Kearifan Lokal Budaya Minangkabau Dalam Seni Pertunjukkan Tradisional Randai Jentera: Jurnal Kajian Sastra, 7(2), 145-160.

Hadie, H. R. (2015). Pengelolaan Seni Di Bale Seni Ciwasiat Pandeglang Banten Universitas Pendidikan Indonesia.

Ihromi. T.O. (2006). Pokok-pokok Antropologi Budaya. Yayasan Obor Indonesia Anggota IKAPI DKI Jaya.

Nahak, H. M. . (2019). Upaya Melestarikan Budaya Indonesia Di Era Globalisasi. Jurnal Sosiologi Nusantara, 5(1), 65-76. https://doi.org/10.33369/jsn.5.1.65-76

Peraturan Daerah Provinsi Sumatera Barat.

Pertiwi, T. C., Suntoro, I., \& Nurmalisa, Y. (2017). Peranan Sanggar Budaya Bandakh Makhga dalam Pelestarian Nilai Budaya Lampung di Sukadanaham. Jurnal Kultur Demokrasi, 5(4).

Primadesi, Y. (2013). Preservasi Pengetahuan Dalam Tradisi Lisan Seni Pertunjukan Randai di Minangkabau Sumatera Barat. Jurnal Kajian Informasi Dan Perpustakaan, 1(2), 179-187. https://doi.org/10.24198/jkip.v1i2.12060

Purnama, Y. (2015). Peranan Sanggar Dalam Melestarikan Kesenian Tradisional Betawi. Patarjala, 461-476.

Putri, M. M., Desfiarni, D., \& Darmawati, D. (2015). Pelestarian Kesenian Randai di Sanggar Minang Saiyo Desa Sijantang Kota Sawahlunto. Sendratasik UNP, 4(1), 37-46.

Rusliana, I. (1990). Pendidikan Seni Tari. Jakarta: Depdikbud.

Silalahi, U. (2009). Metode Penelitian Sosial. Bandung: Refika Aditama.

Sonia, T., \& Sarwoprasodjo, S. (2020). Peran Lembaga Adat Dalam Pelestarian Budaya. Sains Komunikasi dan Pengembangan Masyarakat (JSJPM), 113-124.

Yusuf, A. M. (2005). Metodologi Penelitian: Dasar-dasar Penyalidikan Ilmiah. Padang: UNP Press.

Yusuf, A. M. (2014). Metode Penelitian Kualitatif, Kuantitatif \& Penelitian Gabungan. Jakarta: Kencana. 